\title{
Edirne Kasidesi’nin muhtevası üzerine bir inceleme
}

\section{Nuran BALTA ${ }^{1}$}

\begin{abstract}
APA: Balta, N. (2020). Edirne Kasidesinnin muhtevası üzerine bir inceleme. RumeliDE Dil ve Edebiyat Araştırmaları Dergisi, (19), 355-368. DOI: 10.2900o/rumelide.752352.
\end{abstract}

\section{Öz}

Cumhuriyet dönemi Türk edebiyatının velût şairlerinden biri olan Arif Nihat Asya, sadece ürettiği eser sayısı ile değil, bu eserlerdeki tema çeşitliliği (Türk ve İslâm tarihi, din ve tasavvuf, insan, millî kültür, tabiat, yurt manzaraları) ile öne çıkar. Şairin incelememize konu olan "Edirne Kasidesi” adlı şiiri, onun tarih-mazi-hal ve yurt güzellikleri ekseninde yazdığı şiirlerindendir. Şair, Edirne'yi tarihî zenginlikleri ve tabiî güzellikleri ile anlatırken onu geçmişteki güzellikleri ile hayal eder fakat tarihî gerçeklerle yüzleşmekten de kendini alamaz. Şehrin tarihî eserlerini hayranlık, yıkılan ve kaybolup giden güzelliklerini ise derin bir hüzün ve elemle anlatır. Bu makalede Arif Nihat Asya'nin "Edirne Kasidesi” adlı şiirini, metindeki motifler ekseninde, çeşitli ilmî, edebî ve tarihî eserlerden de istifade ederek tahlile çalıştık.

Anahtar kelimeler: Arif Nihat Asya, Edirne, şiir, Edirne Kasidesi, tarih

\section{A research on the content of Edirne Kasidesi}

\begin{abstract}
Arif Nihat Asya, who is one of the prolific poets of Republic Period Turkish Literature becomes prominent not only with the number of works he wrote but also with the range of theme in these works (Turkish and Islam History, religion and mysticism, human, national culture, nature, country lanscape). The poet's poem called Edirne Kasidesi which is the subject of our study, is one of his poems that he wrote in the axis of history - past state and beauties of the country. The poet imagines Edirne with its beauties in the past while telling it with its historical riches and natural beauties, but he can not help facing historical realities. He tells the historical buildings of the city with admiration and the demolished and lost beauties of the city with deep gloom and anguish. In this article, we have attempted to analyse Arif Nihat Asya's poem called "Edirne Kasidesi" in the axis of pattern of such text by utilizing various scientific, literal and historical works.
\end{abstract}

Keywords: Arif Nihat Asya, Edirne, poem, Edirne Kasidesi, history

\section{Giriş}

Arif Nihat Asya, 1320 / 1904 yılında Çatalca'nın İnceğiz köyünde doğar. Asıl adı Mehmet Arif olan şair, Zîver Efendi ile Fatma Zehra Hanım'ın tek çocuğudur. Daha yedi günlük iken babasını kaybederken, üç yaşında da annesinden ayrılır. Önce akrabalarının yanında, daha sonra da devletin yatılı kurumlarında himaye edilir. İlk eğitimine Örçünlü Köy Mektebi’nde başlar. Ardından sırayla Gülşen-i Maarif Rüşdiyesi, Bolu Sultânîsi ve Kastamonu Sultânîsi'nde tahsilini tamamlar. Mehmet Arif, Balkan Savaşı'nı İstanbul'da, I. Dünya Savaşı ile Millî Mücadele’nin ilk yıllarını Bolu'da ve Millı̂ Mücadele’nin

1 Dr., Bağımsız Araştırmacı (Edirne, Türkiye), nuranbalta@hotmail.com, ORCID ID: oooo-ooo2-466o-0218 [Makale kayit tarihi: 27.04.2020-kabul tarihi: 20.06.2020; DOI: 10.29000/rumelide.752352] 
en hararetli günlerini de Kastamonu'da geçirir. İstanbul'da Dârü'l-Muallimîn-i Âliye (İstanbul Yüksek Muallim Mektebi) ikinci sınıf öğrencisiyken Heykeltraş’ı yayımlar ve Arif Nihat ismini kullanır. 19261927 öğretim yılında İstanbul Yüksek Muallim Mektebi Edebiyat Zümresi’nden mezun olur.

Meslek hayatına Adana Erkek Muallim Mektebi’nde edebiyat öğretmeni olarak başlar. (1930) Bu arada ikinci şiir kitabı Yastığımın Rüyası yayımlanır. Adana'nın çeşitli ortaokul ve liselerinde edebiyat öğretmenliği yaparken 1933 yllında Mevlevî Dede Ahmed Remzi Akyürek ile tanışır. Mevlevî şeyhliğine kadar yükselecek bir "çile" dönemi geçirir. 1942 ve 1943 ylllarında Malatya Lisesi’nde müdürlük ve edebiyat öğretmenliği yapar. 1945 yllında Adana Erkek Lisesi’ne tayin edilen Arif Nihat Asya, 1948 yılında hakkında yapılan soruşturmalar sebebiyle Edirne Lisesi Edebiyat Öğretmenliği’ne gönderilir. (Ylldız, 1997: 15-30).

Büyük şairin Adana'dan sürgün olarak ayrılışı sevenleri tarafından tepki ile karşılanır, Edirne'ye gelişi ise sanat hayatına yeni bir pencere olur. 1948 yılına kadar Edirne'yi hiç görmemiş olan şair, şehrin Osmanlı Devleti'nin "muhteşem bir pây-ı tahtı" olduğunu daha önceden bilmektedir. Sonraki yıllarında Yavuz Bülent Bakiler'e Edirne'nin, Bizans Devleti’nden alındığında "küçük, basit, sade” bir yerleşim merkezi olduğunu, burayı "Balkanların, dünyanın en alımlı, en güzel" şehirlerinden biri, hattâ tarihî zenginlikleri göz önüne alındığında dünyada "iki muhteşem" şehirden biri haline getirenin Türk milleti olduğunu ifade edecektir. Edirne’ye gitmeden önce bu şehir ile ilgili bilgileri Evliya Çelebi ve Lady Montagu'nün eserlerinden okuyan şair, kitaplardan edindiği bilgilerle şehirde birbirinden güzel köşkler, konaklar, saraylar, sebiller, camiler, hanlar ve hamamlar arasında "şehzade ruhuyla ve huzuruyla” yaşayacağını zanneder. Şehrin "hüzünlü, dağınık, yoksul, âdeta terk edilmiş” halini görünce perişan olur. Edirne'yi “yıkılan, dağılan, savrulan bir imparatorluk"a benzetir ve şehri kendini tutamayıp göz yaşları içinde ağlayarak dolaşır:

"Ben, hiçbir şehirde, Edirne'deki gibi ağlamadım. Orada gözyaşlarımı sile sile, yana yakıla evime döndüğüm çok oldu." (Bakiler, 2010: 237-246)²

Şairin incelememize konu olan "Edirne Kasidesi" de bu hüznün kendi tarzı içinde yoğun bir şekilde yansıtıldığı medhiye ve fakat aynı zamanda ağıt sayılabilecek şiirlerinden biridir. Ayrıca bu şiir, araştırmacılar ve eleştirmenler tarafından edebî bir metin olmanın yanı sıra bir şehir rehberi 3 olarak da nitelendirilmektedir. Biz o sebeple, zikredilen mekânlar ve eserler hakkında dipnotlarda ayrıntılı bilgi verme gereğini duyduk.

\section{Edirne Kasidesi}

Arif Nihat Asya, Edirne'de 1948-1950 yılları arasında bir buçuk sene kalır. Edirne'nin tarihî zenginliklerini, mimarî ve tabiî güzelliklerini sanatkâr hassasiyeti, estetik duyuş, dikkat ve tecessüs ile müşahede eder, onları şiirlerinde seslendirir. Şiirlerinin oluşumunda etkili olan faktörler ferdî duyuşlar, günlük hayat, tarih ve mazi, din ve tasavvuf, tabiat ve yurt güzellikleri, destanlar, kıssalar ve halk hikâyeleridir. Bu unsurlar içinde "tarih ve mazi" bilinci önemli bir yere sahiptir. (Ylldız, 1997: 169-

\footnotetext{
2 Türk edebiyatının günümüz şair ve yazarlarından biri olan Yavuz Bülent Bakiler, yirmi yıl Arif Nihat Asya'nın yakın çevresinde bulunur. Kitabında Arif Nihat Asya'ya dair hâtıralarını ve ondan dinlediklerini anlatır. (Bakiler, Y. B. (2010). Ârif Nihat Asya İhtişamı. İstanbul: Türk Edebiyatı Vakfı Yayınları.)

3 Aktaş, Ş. (2011). Millî Romantik Duyuş Tarzı ve Arif Nihat Asya'nın Şiirleri. Arif Nihat Asya / T. C. Kültür Bakanlĭg Kütüphaneler ve Yayımlar Genel Müdürlüğü Anma ve Armağan Kitapları Dizisi / 3 (s. 259-274). Ankara: Kültür Bakanlığı Yayınları; Topaloğlu, Y. (2007). Ahmet Kutsi Tecer ve Arif Nihat Asya’nın SSiirlerinde Edirne. Trakya Üniversitesi Sosyal Bilimler Dergisi, 9 (1), 192-211; Koralp, S. (2019). Tanzimat Sonrası Türk Şiirinde Edirne. Uludağ Üniversitesi Fen-Edebiyat Fakültesi Sosyal Bilimler Dergisi, 10 (37), 1048-1073.
}

Adres

Kırklareli Üniversitesi, Fen Edebiyat Fakültesi, Türk Dili ve Edebivatı Bölümü, Kayalı Kampüsü-Kırklareli/TÜRKİYE e-posta: editor@rumelide.com 
171). Şair, millî unsurlara yer verdiği altı yüz yirmi yedi şiirinin yüz yirmisinde Türk tarihinin ihtişamlı günlerini ve o günlere özlemini işler. (Yıldız, 1994: 545). Bu şiirlerinde ihtişam çağların kahramanlık ve zaferlerini gururla, gerileme ve çöküş devirlerinin elem ve ıstıraplarını ise derin bir hüzünle şiirleştirir.

\section{Edirne'de tarih}

"Edirne Kasidesi”4 de tarih-mazi-hal ekseninde gıpta, hayranlık, gurur; hüzün, hasret ve öfke duygularının hâkim olduğu bir bakış açısıyla yazılır. Bunlar içerisinde baskın duygu, halin realitesi sebebiyle hüzündür. Şair, duygu ve düşünce dünyasına hâkim olan bu hüzün halini şiirin ilk mısralarından itibaren dile getirir. O, Selimiye ve Edirne kelimelerinin birbirlerinden ayrı düşünülmesi mümkün olmayan unsurlar olduğunu ifade eder:

“'Selimiye’ derler 'Edirne' derler; / Tatlı bir gariplik duygusu gelir.” (Asya, 2017: 81)

Devamında ise "eski eser" yoğunluğu bakımından dünyada ikinci sırada yer alan ${ }^{5}$ Edirne'nin tarihî eserlerini "eski eserler kamusu"6 olarak niteledikten sonra bu eserleri âdeta bir film şeridi gibi okuyucunun önüne serer:

"Kemerler, çeşmeler, minarelerle / Bir eski eserler kamusu gelir.

Minarelerden en tatlı ezanlar, / Dallardan güvercin huhusu gelir.

Ayşekadın’a gül ve Yıldırım’a / Üçşerefeli’nin kumrusu gelir.

Şu Selimiye'dir, şu Muradiye.. / Çinilerden sümbül kokusu gelir.

Karşına ya iki sedef çekmece, / Ya iki mücevher kutusu gelir.” (Asya, 2017: 81)

Kemerler, çeşmeler, minareler, "en tatlı" ezanların okunduğu zamanlar, dallarda güvercin huhuları, bir birlik içinde olan Ayşekadın, Yıldırım Bayezid ve Üç Şerefeli Camii, harikulade bir hüsn-i talille çinilerinden sümbül kokusu gelen Selimiye ve Muradiye Camileri, sedef çekmeceler ve mücevher kutuları... Şair, sahip olduğu tarih bilinci ve mazi özlemiyle Edirne'yi geçmişteki güzellikleri ile hayal eder.7 "-Ler" çokluk ekinin on mısrada sekiz defa tekrarı, şehrin tarih ve tabiat zenginliğini vurgular. $\mathrm{Bu}$ esnada yapılan aliterasyon ve asonanslar da bu çokluk ve kesafet duygusunu estetik bir şekilde destekler. Şairin, Edirne'nin tarihî zenginliklerini ve güzelliklerini anlatırken tahayyül ettiği manzaralar; tarihî, mimarî ve coğrafî zemine oturan doku ile uyum içindedir. ${ }^{8}$

4 Asya, A. N. (2017). "Edirne Kasidesi”. Kökler ve Dallar. (s. 81-88). İstanbul: Ötüken Neşriyat. Alıntılar bu baskıdan yapılmıştır.

$5 \quad$ Edirne, bin beş yüz seksen beş tescilli tarihî eseriyle, Floransa'dan sonra dünyada metrekare başına düşen tarihî eser yoğunluğu bakımından ikinci şehirdir. (www.ntv.com.tr/turkiye/floransadan-sonra-en-cok-edirnede, RZ7G9UP3Ko2dNhIXAbz2XQ. Erişim tarihi: 09.03.2020).

$6 \quad$ Kökler ve Dallar adlı kitabın çeşitli tarihlerdeki baskılarında "serler" şeklinde geçen kelimenin doğrusu, bizim kanaatimize göre, vezin ve anlam da göz önüne alındı̆̆ında, "eserler" olmak gerekir. Şairin sanatı üzerine Arif Nihat Asya’nın Şïiri (1994) adıyla doktora çalışması bulunan Prof. Dr. Saadettin Yıldız da kendisi ile yaptı̆̆ımız görüşmede bu hususu teyit etmiştir.

"Arif Nihat'ın şiir üslûbunda buna benzer 'hayal temerküzleri’ne çok sık rastlanır. Belli bir varlık veya kavramı, çok değişik yönlerden ele aldığını, onu âdeta çok boyutlu bir varlık veya kavram haline getirdiğini gösteren bu tutum, onun üslûbunun baslıca özelliklerinden biridir.”.” (Yıldız,1997: 370).

Edirne'den "ulu şehir, büyük sur, yakın belde, hastalıkları gideren ve rahatlık veren" (Evliya Çelebi, 2012: 549) şeklinde övgü dolu sözlerle tanıtan Evliya Çelebi, Seyahatnâmesi’nde "Ulu Cami” olarak adlandırdığı Eski Camii anlatırken o dönem Edirne'de yaşanan güzelliklere dair bilgiler verir. Cami cemaati, mihrap önündeki İrem Bă̆ı'nı kendilerine yuva yapan güzel sesli kuşların dokunaklı sesleri ile canlılık kazanırken, bahçedeki menekşe, lâle ve erguvan çiçeklerinin hoş ve güzel kokuları ile dolar. Sümbül, zanbak mevsiminde ise camide "nice yüz adet" çiçek, vazo veya saksı içine konularak saflar arasına yerleştirilir ve böylece caminin içinin "misk" kokulu olması sağlanır. (Evliya Çelebi, 2012: 561). Aynı şekilde Üç Şerefeli Camii de cami cemaatinin dışarı çıkmak istemeyeceği bir güzellikte anlatılır. Caminin etrafındaki gül ve lâle bahçesinden toplanan çiçekler, "fağfurî ve kâşî çini" saksılar içine konularak saflar arasına dizilir. Caminin içi hoş ve güzel kokular ile dolar. (Evliya Çelebi, 2012: 563) Edirne'yi Evliya Çelebi'den bu özellikleri ile okuyan ve hayal eden Arif Nihat Asya, geçmiş yıllarda camilerde oluşturulan nezih ve ferah ortamın bugün de olmasını temenni eder: "Ah 
Şair, "iki sedef çekmece" ve "iki mücevher kutu" imajları9 ile Selimiye ve Muradiye Camilerini10 kastetmiş olabileceği gibi, içine Kur'ân-ı Kerîm ve cüzlerinin, sakal-ı şerîfin, mücevherlerin konulduğu çekmeceleri de demek istemiş olabilir. Nitekim 16. ve 17. yüzyılda Osmanlılarda çekmece yapımı bir sanat dalı olarak kabul edilir ve İstanbul ile Edirne'deki sert ağaçlardan ince bir işçilikle çekmeceler yapılır. Oyma, sedef, fildişi tekniklerinin uygulandığı ahşap işçiliği ile cüzlerin korunması için Kur'ân çekmeceleri, Hz. Peygamber'in sakal tellerini muhafaza etmek için sakal-ı şerîf çekmeceleri imal edilir. (Yücel, 1993: 251-252).

1361 yllında Osmanlılar tarafından Orhan Bey zamanında oğlu I. Murat'ın sistemli fetih siyaseti ile fethedilen şehir Osmanlı Devleti'nin Bursa'dan sonra ikinci başkenti olur. (Halil İnalcık, 1993: 138159; Gökbilgin, 1994: 425-431) 1453'te İstanbul'un fethine kadar doksan iki yl Osmanlı Devleti'nin başkenti (payitahtı) olarak birçok tarihî olaya sahne olurken, sultan, vezir, paşa gibi birçok makam ve mevkiden devlet ricalini (I. Murat, I. Bayezit, Süleyman Çelebi, Musa Çelebi, I. Mehmet, II. Murat, II. Mehmet, II. Bayezit, I. Selim, I. Süleyman, II. Selim gibi) ağırlar. Şair, Edirne’nin tarihî zenginliğe ve mirasa sahip olmasında büyük katkısı olan ecdadı şöyle anlatır:

"Vezirlerin iki tuğlusu gider, / Arkasından yedi tuğlusu gelir.

Şurda abdest alır Hudavendigâr; / Yerden suyu, gökten havlusu gelir." (Asya, 2017: 81).

Türk tarihinde "hükümranlık ve bağımsızlık anlamları taşıyan, bayrak, sancak, alem gibi askerî ve siyasî bir güç ve yetki işareti” olan tu ğun sayısı, vazifenin derecesi ve önemine göre değişir. Osmanlılarda padişahın yedi, veziriazamın beş, vezirlerin üç, beylerbeyinin iki, sancakbeyinin ise bir tuğu vardır. (Çoruhlu, 2012: 330-332). Edirne'de de geçmiş yllarda "iki tuğlusu"ndan (beylerbeyi) "yedi tuğlusu"na (padişah) birçok devlet büyüğü görev yapar. Şair ayrıca Edirne fethinin başkahramanı I. Murat'in (Hudâvendigâr) abdest alırken "yerden suyu, gökten avlusu” gelir diyerek onun dini yaşama bakımından manevî gücünü ve Allah'ın yardımına mazhar oluşunu vurgular. I. Murat, Osmanlı kaynaklarında hayır yapmayı seven, adaletli, hayatını gazâya sarfeden bir hükümdar; Bizans kaynaklarında ise az ve güzel konuşan, büyük azmiyle düşmanlarına karşı daima başarıll, hataya tahammülü olmayan, Hristiyanlara karşı merhametli bir sultan olarak anlatılır. I. Murat, Balkanlara egemen olmak hedefiyle gazâ için altı defa Rumeli'ye geçer. Kendisini Tanrı ilhamına mazhar olan "bir velî gibi hisseden" sultan, gazâyı dinî bir vazife telâkki eder. (İnalcık, 2006: 162-163)

\section{Nehirler}

Arif Nihat, “mahzun Edirne”yi anlatmaya devam eder. Bu kez sırada Edirne’nin nehirleri vardır:

“Dedeler, adına 'Meriç' demişler: / Sinırdan bir ana kuzusu gelir.

Arda'dan su içer turnalar, akşam; / Tunca'ya Tuna'nın kuğusu gelir.

Bülbül Adası'nı görsen sanırsın / Meriç'le Tunca'nın yavrusu gelir.

Bir yelpaze açar vadi, çiçekten.. / Yurdunun şahane tavusu gelir.

Kovanlar, bahçeler birbirlerinin / Ovada kapı bir komşusu gelir.

Kovanlar, bahçeler, bağlar üstüne / Akşamın ya sisi, ya pusu gelir.

keşke, Türkiye'deki bütün câmilerin mihrab önlerine, saflarının aralarına yine öyle eskisi gibi bin bir renkli, bin bir kokulu çiçek saksıları koyabilsek." (Bakiler, 2010: 239). Devamında da bu güzel uygulamadan niçin vazgeçildiğini anlayamadığını ifade eder. Ona göre Evliya Çelebi’nin anlattığı güzellikleri daha da ileriye götürecek bir anlayışa çok ihtiyaç vardır. (Bakiler, 2010: 241).

9 İmaj: “İmge.” (TDK, 2005: 960).

10 Arif Nihat Asya, "Murâdiye" şiirinde Selimiye Camii’ni Murâdiye Camii’ni selâmlarken hayal eder: "Ağlama, ey Murâdiye: / Geliyor çifte bayramlar! / İşte, Selimiye, karşı / Tepeden seni selâmlar.” (Asya, 1976: 11). 
Sular der ki: ‘uyu Edirne’m, uyu!' / Mahzun Edirne’nin uykusu gelir...

Meriç, Tunca, Arda, Tuna ve Bülbül Adası, tıpkı geçmiş yıllarda olduğu gibi bir aile birliği içinde hareket ederler. Turnalar, Arda nehrinden su içerken, Tuna'nın kuğusu Tunca'ya gelir. Tuna'daki kuğunun Tunca'ya yani Edirne'ye gelişine Edirneliler zaman zaman şahit olurlar. Tuna havzasında sert geçen kış aylarında kuğu, turna, yaban kazı ve yaban ördeği gibi kuşlar, Balkanları aşıp daha ılıman buldukları güneye, Trakya'ya kadar inerler. Meriç, sınırdan gelen bir ana kuzusudur. Şair, Meriç’i “ana kuzusu"na benzetirken onu Bulgaristan'ın Filibe yakınlarında doğduğu noktada bir kuzu veya Tuna'ya göre daha küçük bir nehir olması sebebiyle de Tuna'nın yavrusu olarak düşünmüş olabilir. Meriç ve Tunca nehirleri arasında, içerisinde bahçelerin bulunduğu ve bülbüllerin çokluğundan dolayı Bülbül Adası ismini (Kahrıman, 2017: 33) alan ada ise şair tarafından coğrafî konumu dikkate alınarak Meriç ve Tunca'nın yavrusuna benzetilir. Nehirlerin bulunduğu havzada kovanlar, bahçeler, bağlar bulunur. Vadide bir yelpaze gibi yayılan çiçekler ise parlak ve güzel renkleriyle bilinen tavus kuşuna benzetilir. ${ }^{11}$ 121314

11 Onuncu ve on birinci Hicrî asırda (MS. 16. ve 17. yüzyıl) Tunca ve Meriç sahilleri, İstanbul'da Damat İbrahim Paşa'nın Sâdâbâd'ını hatırlatırcasına güzelleştirilerek imar edilir. Halk sahillerde gezinirken nehirlerde saraya, vezirlere, zevk ve sefa ehline ait süslü kayıklar dolașır ve bu kayıkların sırmalı püskülleri nehrin yüzeyinde yaldızlı akisler olușturur. İlkbaharın gelişiyle Edirneliler, dedelerinin güzel vakit geçirdikleri Bülbül Adası’na, Kasımpaşa burnuna arabalar ile, çoğunlukla da kafileler halinde yürüyerek gelirler. Tunca sahillerinde oturarak vakit geçirirler. (Tosyavizade Doktor Rufat Osman, 2015: 130-131).

Edirne’nin Meriç, Tunca ve Arda nehirleri Osmanlı dönemi şiirlerine de konu olur. Divan şairleri bu nehirleri orijinal benzetmelerle tasvir ederler. Bunlardan birkaçını şöyle sıralayabiliriz: Nef̂̂, "kıymetli hazineyi (padişah) korumak için bekleyen yılanlar”a, Nev'î, "gönlü susamış âşıklara vuslatını sunan Edirne güzelleri”ne, Edirneli Hibrî ise "altlarından irmaklar akan cennetler"e benzetir. (Gürgendereli, 2016: 21-26).

12 Lady Montagu, III. Ahmet devrinde İngiltere'nin İstanbul elçisi olarak görev yapan Wortley Montagu'nün eşidir. Eşinin elçilik vazifesi sebebiyle tayini İstanbul'a çıkınca Londra'dan İstanbul'a gelir. Bu seyahati esnasında Rotterdam, Lahey, Köln, Nürnberg, Viyana, Prag ve Hannover sehirlerini dolașir ve Petervaradin-Belgrat-Edirne yoluyla İstanbul'a gelir. Dönemin toplum hayatına dair gözlemlerini bir belge niteliğindeki mektuplarıyla gözler önüne serer. (Montagu, 1998: 57) 1717 yılında Edirne'de bir aydan fazla bir süre kalan Lady Montagu, Edirne'den Londra'ya gönderdiği mektuplarından birini, Tunca kenarında oturduğu bir evden yazar. Nehrin suyu, bu evin odalarının pencerelerinin altından akar. Yüksek servilerle örtülü olan bahçesinde gün boyunca türlü türlü cilveler yapan birçok güvercin vardır. Nehrin kenarlarındaki meyve ağaçlarının altında ise "kibar takımları" eğlenirler: "Çayırlarda ve gölgelik yerlerde halkavari toplanıyorlar, yere kilim seriyorlar, üzerine oturuyorlar, bir taraftan hizmetkârlardan biri saz çalıyor, öbür taraftan onlar da kahve içiyorlar." (Montagu, 1998: 47).

13 Roman, hikâye, siir türünde yazdığı eserlerle tanınan Raif Necdet Kestelli, Balkan Harbi sırasında Edirne’de Redif Taburu Kumandanlığı görevinde ve Bulgaristan'daki altı aylık esaretinde yaşadıklarını, bu yıllarda Edirne'nin mahzun halini hâtıra kitabında yüreklere dokunurcasına anlatır. (Kestelli, 2001.) Balkan Harbi’nde Edirne'de asker olarak bulunan yazar Raif Necdet Kestelli, Edirne’nin Bulgarlar tarafindan işgali sirasında esir düșer. İçinde bulunduğu kafile ile birlikte Bulgar subayları ve askerleri eşliğinde Edirne'den ayrılırken Tunca nehrinin kenarından geçerler. Yazar, gördüğü nehir manzarası karşısında derin bir elem duyar:

"Şimdi Tunca'nın kenarından geçiyoruz. Lâtif ve cazip kıvrmlarla uzanmış bu güzel tabiatı bütün bekâret ve şïriyetiyle düşmana terk etmek ve gitmek.. Lâkin biz bu kadar büyük bir felâkete, bu derece derin bir eleme maruz kalmış olmak için dünyanın nasıl birinci sınıf bedbahtlarından olmalıyız, Yarabbi!..” (Kestelli, 2001: 78).

14 Enis Behiç Koryürek’in öğrencilik yılları Trablusgarp ve Balkan Savaşlarına, memuriyet hayatı ise I. Dünya Savaşı’na denk gelir. 1915 yılında Bükreş Konsolos Kâtipliği, 1916 yılında Budapeşte Konsolos Kâtipliği’nde çalışır. 1922 yılında ise Edirne Vilâyeti Hukuk İşleri Müdürlügü’ne tayin edilir. (Çandır, 2014: 31-34.) Enis Behiç Koryürek de tıpkı Arif Nihat Asya gibi Edirne'ye hüzünle bakar. Şair, hem tahsil hem de meslek hayatında Balkan Savaşlarında yaşanan acıları derinden hisseder. Bu duygularını şiirlerinde sanatkâr ruhu ve vatan aşkıla etkili bir şekilde anlatır. "Ey Meriç!" adlı şiirini Edirne'nin düşmandan geri alınması vesilesiyle terennüm eder:

"Ey Meriç, hasretle yandım; ak, dökül nîrânıma! / Kevserin versin teselli sönmeyen hicrânıma! Ayrı düştüm nâzenin sahillerinden münhezim, / Ah, bilsen.. Ah, bilsen.. Ben yetimim, sensizim. Sen de ayrıldın mı (ay-yıldız) dan ey dilber Meriç?. / Kanlı zulmetler midir sînende artık muhteliç?. Of, tarih ağlıyor; fikrim perişan ağlıyor.. / Gözyaşım gûya senin menbalarından çağlıyor. Çağlayan menbaların vaktiyle Türk'ün hükmüne / İnkıyat eylerdi; düştük biz fakat günden güne. Gitti elden bir muazzam, nazlı hemşiren: Tuna! / Ah, o gün biz bir azim iklim verdik düşmana. Sendin artık bir teselli, ey Meriç, hüsran için. / Ayrılıp kız kardeşinden bizler olduk kardeşin.

Şair, suyunu "Kevser suyu"na benzettiği Meriç’in hasreti ile yanar. Meriç'e kavuşunca onsuz bir yetim olduğunu, onun bir zamanlar bayraktan ayrı düştüğünü, "kız kardeşi” Tuna'nın elden gittiğini ve artık kardeşinin Türk milleti olduğunu, Meriç ile teselli bulduğunu çarpıcı bir şekilde dile getirir. 
Akşamın karanlığı bağların, bahçelerin üstüne sis ve pus ile birlikte çöker. Şair teşhis sanatıyla nehrin sularını ve Edirne'yi kişileştirirken, intak sanatıyla "Sular der ki: 'uyu Edirne’m, uyu!'” diyerek suları konuşturur. İstiare sanatı ile de Edirne’yi hüzünlü bir insana benzetir. Nehrin suları, âdeta bir insan hüviyetine girerek Edirne'nin uyuması için, şırıltıları ile ninni söyler. Edirne, bu ninniler eşliğinde ve onu saran hüznüyle uykuya dalar. İmparatorluğun çöküş sürecini, Balkan Harbi’nden başlayarak savaş yıllarını ve Cumhuriyet’in kurulduğu dönemin sıkıntılarını yaşayan Arif Nihat Asya'da hüzün, eserleri boyunca daimi temlerden biridir. Edirne Kasidesi’nin bu bölümünde hüzün teminin, "sular" ve Edirne arasındaki diyalog halinde şairane bir ustalıkla dile getirildiği görülmektedir.

\section{Edirne güzelleri}

Edirne'nin güzelliklerini anlatırken Edirne güzellerini de unutmayan Arif Nihat Asya, Edirne'nin hanımlarını, güzel gözleri, inceliği ve zarifliği ile bilinen âhuya (ceylana) benzetir. Bu hanımlar, beyaz tenli, duru bakışlı, az konuşan, konuştuğu zaman da insanın ruhunu aydınlatan ve saçları ıtır kokan güzellerdir:

“Görürsün yollarda bir başka yavru; / Sana Edirne’nin ahusu gelir.

Şimdi göğüslerin en haşarısı, / Şimdi dudakların en uslusu gelir.

'İşte tenlerin en beyazı!' derken / Bakışların da en durusu gelir.

Söyletebilirsen, konuşturursan / Ruha sanki dupduru su gelir;

/ Saçlarından itır kokusu gelir." (Asya, 2017: 83)

Evliya Çelebi de Edirne güzellerini şaire benzer bir şekilde tasvir eder. Ona göre Edirne güzelleri, ceylan gözlü, inci dişli, şirin sözlü, güzel ve nur yüzlü, hal ve tavırları ölçülü, konuşmaları düzgündür. Misk kokan kâkülleri bölük bölüktür. Eda, cilve ve nazlarıyla onları gören âşıları hayran bırakırlar. (Evliya Çelebi, 2012: 604-612) Lady Montagu ise Edirne'deki kadar güzel ve gür saçlı kadınlara başka yerlerde rastlamadığını, buradaki hanımların hemen hepsinin güzel, gözlerinin kara ve tenlerinin "dünyanın en güzel renginde" olduğunu ifade eder. (Montagu, 1998: 43)

\section{Camiler}

Okuyucuya Edirne'yi, Yahya Kemal'i andıran derin bir tarih duygusu ve yoğun bir mazi hasreti içinde adım adım dolaştıran Arif Nihat Asya, "Edirne Kasidesi”nin burasında sözü Edirne'nin selâtin camilerine getirir:

“Taşları kararmış bir yol ucunda / Üçşerefeli’nin kapusu gelir.

Şu yana dönersen Eskicami’nin / Kesilmiş, biçilmiş avlusu gelir.

Atınca üç adım daha ileri / Bir serin kubbenin kuytusu gelir.

Dünyanın en güzel minareleri / Ve kubbelerin en ulusu gelir;

…….............. / Türk'ün Trakya'da tapusu gelir.”

Mihrabında bir teravih kılmaya / Denizler ardından yolcusu gelir.

Bilsen ki bağrında kanar bir yara / Yarasını sarmak arzusu gelir.

Mahya olmak için Sultanselim'e / Göklerden yıldızlar ordusu gelir.

Kubbeler menekşe, şerefeler gül... / Mermerlerinden çiğdem kokusu gelir.” (Asya, 2017: 84) 
Şair, şiirin başında "eski eserler kamusu” diyerek sıraladığı Edirne'nin mabetlerini bu bölümde en büyük pâyeyi Selimiye Camii’ne vererek, onu, öne çıkan mimarî özellikleri ile anlatır. Üç Şerefeli Camii'nin kapısı15, Eski Camii'nin avlusu ve Selimiye Camii'nin ise menekşeye benzetilen serin ve ulu kubbesi, şerefeleri güle benzetilen dünyanın en güzel minareleri ve çiğdem kokan mermerleri, bu eserlerin, başka yapılarda rastlanmayacak özellikleridir. Her Ramazan ayında mihrabında teravih namazı kılmak için şehir dışından birçok insanın akın ettiği, Balkan Savaşı'nda gördüğü tahribat ${ }^{16}$ sebebiyle yaralarını sarmak arzusunun uyandığ "göklerden yıldızlar ordusu"nun geldiği müstesna mabet Selimiye, Türk milletinin "Trakya'da tapusu"dur. ${ }^{18}$ Samiha Ayverdi de tıpkı Arif Nihat Asya gibi Edirne'ye, şehrin tarihî eserlerine derin bir sevgi ve hüzünle bakar. Yazar Edirne için "Türk tarihinin dört yol ağzı", "şevket ve azamet devirlerinin taht ve ordugâh şehri (...), sonunda da çöküş ve gerileyiş günlerinin sedd-i İslâmı olacak olan bu gün görmüş belde" derken Selimiye camiini ise "Rumeli'nin kalbi", "Edirne şehrinin üzerine vurulmuş kilit" ve "sedd-i İslâma bekçi” olarak niteler. (Ayverdi, 1975: 247-248, 380-381).19

Çocukluğundan itibaren resme duyduğu ilgi ile "görme"ye dayalı imajlara önem veren ve aynı zamanda çiçeklere de büyük bir ilgi ve sevgi besleyen (Ylldız, 1997: 381-429) Arif Nihat Asya, Selimiye Camii'nin kubbesini menekşeye, şerefelerini güle benzetir. Ramazan ayında Selimiye Camii’nin minarelerine asılan mahyaları ise, hüsn-i tâlil sanatı ile, gökten gelen yıldız ordusunun oluşturduğunu söyleyerek şairâne bir sebep tahayyül eder. Şairin redif ve kafiye ustalığı ise 11'li hece ölçüsü ile her biri konuya uygun seçilmiş kelimesi kadrosu içinde yer alan -usu seslerinden oluşan âhenk ile (duygusu, kamusu, huhusu, kumrusu, kokusu, kutusu, tuğlusu, havlusu, kuzusu, kuğusu, yavrusu, tavusu, komşusu, pusu, uykusu, ahusu, uslusu, durusu, dupduru su, kapusu, avlusu, kuytusu, ulusu, tapusu, yolcusu, arzusu, ordusu, konusu, doğrusu, namlusu, kuyusu, koşusu, kaygusu, borusu, buğusu, Şumnu'su, kurusu, korusu, koyusu, pazusu, avcısı, puhusu, dolusu, duygusu, kutlusu, Samanuğrusu, arzusu) sağlanırken "gelir" rediflerinin şiir boyunca tekrarları ile de süreklilik, bolluk ve zenginlik çağrışımları yapılır. Sıfatların derecesini arttıran "en” zarfı ile de Edirne’nin tarihî, mimarî, coğrafî ve kültürel bakımdan üstün yanları (en doğrusu, en güzel korusu, en kutlusu, en uslusu, en durusu, en ulusu) ustalıkla anlatilır.

15 Edirne’nin selâtin camilerinden biri olan ve adını üç serefeli minaresindan alan Üc Serefeli Camii’nin beş kapısı vardır. İç kısmın (harîm) da dışarıya açılan üç kapısı vardır. Rıfat Osman, halk arasında güzelliğiyle meşhur olan kapının cümle kapısı olduğu zannedilse bile, asıl bu kapılardan kule tarafında olup mermer teresaya çıklan kapının sade ve zarif süslemeleri, mermer nakışları, etrafındaki sütun ve şekilleriyle şöhrete sahip olması gerektiğini ve Osmanlılar tarafından bu kapıya benzer bir kapının diğer câmilerde inşa edilmediğini ifade eder. (Tosyavî-zâde Doktor Rifat Osman, 1999: 50.)

16 Gazi Mustafa Kemal Atatürk, 21 Aralık 1930'da Edirne’ye üçüncü gelişinde şehirdeki tarihî eserleri gezer. Bir "sanat şaheseri” olarak nitelendirdiği Selimiye Camii'ni gezdiği sırada Balkan Savaşı’nda câmiye isabet eden top mermilerinin izlerini ve yıkıntılarını görünce şöyle der: "Bunları onarmayınız, olduğu gibi kalsın. İnsanlığa mal olmuş bir sanat şaheserine karşı, düşmanın insafsızca, saygısızca davranışı bütün dünyaya örnek ve ibret olsun.” (Önder, 1998: 6-9.)

17 "Özellikle ramazan aylarında birden fazla minareli câmilerin iki minaresi arasına kurulan ışıklı yazı veya resim panasu" anlamına gelen mahya, bir gelenek olarak İstanbul, Edirne ve Bursa'da yaşatılır. Edirne'de Beyazıt, Üç Şerefeli ve Selimiye Camilerinin minarelerine mahya kurulurken, tek minareli camilerde ise "kaftan giydirme" denilen bir usul uygulanır. Buna göre câmilerin minareleri külâhından küpüne kadar yukarıdan aşağıya kandillerle donatılır. Edirne şehrinin Bulgarlardan geri alındığı günlerde Selimiye Camii’nin dört minaresine de kaftan giydirilir. (Bozkurt, 2003: 396-398.)

18 Yahya Kemal, hiçbir milletin Türk milleti gibi kısa sürede gönül birliğini sağlayarak yaşama hakkını kazanamadığını belirtir. Ona göre, Türk milleti, ebedî yaşama hakkına sahip olduğunu İstanbul, Edirne ve Bursa'daki minareler, Millî Mücadele ylllarında ise bunu milletin timsali Mustafa Kemal'in etrafinda oluşan birlik ile gösterir. (Beyatll, 2008: 4546) Şair, bu davada Edirne'nin hak, esas ve barışın temel taşı olduğunu söyler. (Beyatll, 2008: 205) "Bu devlet tam manasiyla Edirne'de kuruldu.” diyerek siyasîlerin Edirne meselesini kesinlikle ihmal ve imhal etmemesi gerektiğini önemle vurgular. (Beyatl, 2008: 305.) Bütün bu düşünceler ışı̆̆ında Yahya Kemal'in de Arif Nihat Asya gibi Selimiyeye dolayısıyla Edirne’ye “Türk’ün Trakya”daki tapusu” olarak baktığı söylenebilir.

19 Tarih-i Edirne adlı eserde ise Edirne'den "Pes bu şehrin fazileti malûm-ı meşhurdur, bundan yeni ve yegregi (daha iyisi) Kâbe-i Mükerreme'dir ve Medîne-i Münevvere ve Kudüs-i Şerîfdir" denilerek övgüyle bahsedilir. Devamında ümmetin âlimlerinin ve ehl-i sünnet fazilet sahibi kişilerin Edirne için "Dârü’n-nasr" ve "gaziler ocağı"dır dedikleri ve bu sebeple kesinlikle elden çıkarılmaması gerektiğini söyledikleri ifade edilir. (Tarih-i Edirne, Hikâyet-i Beşir, 1960: 15).

Adres

Kırklareli Üniversitesi, Fen Edebiyat Fakültesi, Türk Dili ve Edebivatı Bölümü, Kayalı Kampüsü-Kırklareli/TÜRKIYY e-posta: editor@rumelide.com
Adress

Kurklareli University, Faculty of Arts and Sciences, Department of Turkish Language and Literature, Kayalı Campus-Kurklareli/TURKEY e-mail: editor@rumelide.com 
Arif Nihat Asya, Edirne'deki selâtin câmilerinin hâlâ ayakta olması ile teselli bulur. Selimiye Câmii’nin ${ }^{20}$ bütün görkemiyle varlığını sürdürdüğünü dile getirir. Ona göre Selimiye "taşın, mermerin, kubbenin, minarenin, şerefenin mükemmel ölçülerle şiirleşmesi”dir. Şair, Mimar Sinan'ın, hayatı boyunca sadece Selimiye'yi yapmış olsaydı bile onun "dünyanın en büyük mimarları" arasında sayılabileceğini ifade eder. Selimiye karşısında "kolsuz kanatsız, ağızsız-dilsiz" kaldığını ve "Esas şiir, Selimiye'nin ta kendisidir." diyerek Doğu ve Batıda ondan daha muhteşem bir mabedin olmadığını söyler. (Bakiler, 2010: 239-240).

Arif Nihat Asya, Selimiye Camii’ne duyduğu hayranlığı, "Selimiye" şiirinde de dile getirir. Şair, şiirinde Selimiye Camii’ni "kuğu”ya benzetirken, onu tarihten miras, Mimar Sinan'ın "şanlı hediyesi” olarak görür:

"Selim'lerden kalma muhteşem mîras,

Sinan'lardan kalma şanlı hediye;

Kuvvetin turası, sanatın mührü,

Kubbeler kubbesi bir Selimiye.

İşte tarih, işte batıyla doğu...

Görenler, göstersin böyle bir kuğu! ...” (Asya, 1976: 14)

\section{Karaağaç}

20. yüzyıla kadar geniş bahçeli evleri, konakları ve eğlence mekânları ile Edirne'nin müstesna bir köşesi olan Karaağaç, Arif Nihat Asya’ya 1948-1950 yllarında başka bir çehre ile görünür:

"Yazık ki yıkılmış Karaağaç’tan / Bugün, artık, ağıt konusu gelir!

Edirne’ye 'mahzun Edirne’ sözü, / Şimdi sözlerin en doğrusu gelir.

'Şu köprü, köprümdür... geçeyim!' dersin... / Önüne yabanın namlusu gelir.

Şimalde bahçene çkmak istesen / Yolunu bekliyen bir pusu gelir.

/ Ve hiyanetlerin kuyusu gelir.

'Nerdesin ey tarih!' desen, gözüne / Serdengeçtilerin koşusu gelir.

'Hani torunum?' der şehit ruhları; / Sana bir imtihan kaygusu gelir..

/ Cevap verememek korkusu gelir.” (Asya, 2017: 85)

$20 \quad$ II. Selim'in emriyle Hicrî 976-982 (1568-1574) ylları arasında inşa edilen Selimiye Camii’nin mimarı, yapılıșı ve mimarî özellikleri ile ilgili olarak birçok kaynakta önemli bilgiler vardır. Sâî Mustafa Çelebi, Mimar Sinan'ın, Edirne'ye son derece sevgisi ve şefkati bulunan II. Selim'in emriyle dünya halkının beğenisini kazanmayı hak edecek çok büyük bir câmi inşa ettiğini söyler. Sağlamlı ve estetik bakımlarından fevkalade özelliklere sahip olan Selimiye’nin, onu ilk defa görenleri öncelikle etkileyen öğesi; çok kuvvetli hayranlık ve huşû tesiri bırakan kubbesidir. (Sâi Mustafa Çelebi, 2003:81). Evliya Çelebi ise, II. Selim'in, rüyasında Hz. Peygamber'i gördüğünü ve peygamberin ondan Edirne’de bir cami yaptırmasını istediğini yazar ve bunun üzerine sultanın, Kıbrıs fethinden elde edilen ganimetlerle "Koca Mimar Sinan”a camiyi yaptırdığını anlatır. (Evliya Çelebi, 2010: 569-577).

Türk edebiyatının Cumhuriyet döneminde roman, hikâye ve hâtıraları ile öne çkan yazarlarından Nahit Sırrı Örik, Edirne'yi gezip dolaşarak şehrin tarihî zenginliklerini ve tabiî güzelliklerini anlattı̆̆ Bir Edirne Seyahatnâmesìnde Selimiye'yi, Mimar Sinan'ın, ziyaretçilerini şaşkın ve hayran bırakan, gökyüzüne "kâinat azametiyle" yükselen, "dehanın en muazzam mahsulü" ve Edirne'ye gelme'yi "farz" kılan eseri olarak anlatır. (Örik, 2000: 17-45.)

Edirne ve tarihî eserleri için ayrıca bk.: Abdurrahman Hibrî (1999). Enîsüll-Müsâmirîn (Edirne Tarihi) (R. Kazancıgil, çev). İstanbul: Edirne Valiliği Kültür Yayını; Ahmet Bâdi Efendi (2014). Riyaz-ı Belde-i Edirne I. Cilt (N. Adıgüzel-R. Gündoğdu, haz.). İstanbul: Trakya Üniversitesi Yayını; Aslanapa, O. (2003). Edirne'de Osmanl Devri Abideleri. İstanbul: Edirne Valiliği Kültür Yayınları.; İnalcık, H. (1993). Edirne'nin Fethi. Edirne'nin 6oo. Fetih Yrldönümü Armağan Kitabı (s. 138-159). Ankara: Türk Tarih Basımevi; Kuban, D. (1997). Sinan’n Sanat ve Selimiye. İstanbul: Türkiye İş Bankası Kültür Yayınları; Kuruyazıcı, H. (1993). Selimiye Camisi'nin Kubbe Boyutları. Tarih ve Toplum Aylık Ansiklopedik Dergi, 20 (120), 24-27; Peremeci, O. N. (2011). Edirne Tarihi. Edirne: Bellek Yayınları. 
Şair, Balkan Savaşı ve I. Dünya Savaşı'na maruz kalan, 1920-23 yılları arasında Yunan işgaline uğrayan Karaağaç'ın, ${ }^{21}$ yaşadığı acılar, felâketler ve yıkımlar sebebiyle bugün "ağıt konusu” olduğunu söyler. Bir zamanlar Türk topraklarında yer alan fakat daha sonra Arda nehri üzerinde Yunanistan ile Türkiye arasında sınır teşkil eden demir yolu köprüsünün bir başında Mehmetçik, diğer başında Yunan askeri nöbet tutmaktadır. Bu hal şaire dokunmuştur. Zira o köprü artık sadece bizim değildir. Bir yarısından "yaban" da onu sahiplenmiştir. Şair, "hıyanetlerin kuyusu" ile de Balkan Savaşı esnasında siyasî ve askerî alanlarda yaşanan hıyanetleri kastetmiş olabilir. Dönüp tarihe baktığında fetihten fethe koşan, millî ve manevî değerler uğruna gözünü kırpmadan canını veren serdengeçti ecdâdını hatırlar ve onların “Hani torunum?” sorusuna yüz akıyla cevap veremeyeceği endişesini taşır. Bir zamanlar Türk bayrağının dalgalandığı toprakların kaybedilişi ve bu sırada Edirne'nin ruhundan ve özünden kayıp giden parçalar, şairi derinden yaralar. Bu sebeple Edirne için söylenecek "en doğru söz"ün "mahzun Edirne" sözü olduğunu belirtir.

\section{Kiylk}

Şair, derin acıların ve yıkımların yaşandığı savaş yıllarını hatırlamaya devam eder, sözü Kıyık semtine ve oradaki tabyalara getirir:

“Çık da yeri, göğü dinle Kıyak’ta: / Tabyalardan hücum borusu gelir.

Tüter.. buram buram tüter topraklar; / Topraklardan barut kokusu gelir.

Doya doya doldur göğsünü yolcu: / Genzine Arda’nın buğusu gelir.

Silinir tepeler, silinir dağlar; / Filibe'si, Sofya'sı, Şumnu'su, gelir.

/ Ve Kızanlık'tan gül kurusu gelir.” (Asya, 2017: 86)

Arif Nihat Asya, mustarip Edirne tablosunu, "yıkılmış" sıfatıyla nitelediği Karaağaç’tan sonra Balkan Harbi esnasında şehir kuşatma altında iken tabyalardan gelen top sesleri ve mukaddes vatan topraklarında kahraman şehit ruhlarının tütmesi (barut kokusu) ile destekler. Şehrin tarihteki ihtişamlı haline göre gerilemişliğini ve yaşadığı tahribatı derinden hissederek estetik bir duyuşla şiirleştirir. Balkan Savaşı'nda Edirne'nin müdafaasında Kıyık tabyası ve Edirne kalesi22 önemli bir rol oynar. Kale komutanı Mehmet Şükrü Paşa ve emri altındaki birlikler, dışarıdan hiçbir yardım almamalarına rağmen, şiddetli taarruz ve işgallere karşı beş buçuk ay direnirler. 26 Mart 1913’te Bulgar-Sırp işgaline uğrayan Edirne, üç ay sonra 19 Temmuz 1913’te geri alınır. (Örenç, 2013: 103134). Arif Nihat Asya, Edirne müdafii Mehmet Şükrü Paşa'nın "müthiş bir komutan” olduğunu, paşanın büyük vatanseverliğinin bir nişanesi olan vasiyetinin ${ }^{23}$ kendisini ağlattığını ifade eder. (Bakiler, 2010: 244-245).

\footnotetext{
$21 \quad$ Karaağaç, Balkan Savașı'nda Bulgarların eline geçer. I. Dünya Savașı sırasında yedi ay Fransız Askerî Hükümeti’ne merkezlik yapar. Yunanlılar tarafından 1920-23 yılları arasında işgal edilir. Lozan Antlaşması'ndan sonra 1923’te Türk hükümetine devredilir. (Emekligil, 2013: 25-27.) Ali Fuat Örenç, "İngiliz Belgeleri’nde Balkan Harbi Edirne Kuşatması 1912-1913" yazısında Edirne ve Karaağaç'ın isgaline dair bilgiler verir: "Samson Kasım ve Aralık aylarında șiddetlenen Edirne bombardımanında şehrin gördüğü zarara ayrıca yer ayırmıştı.21 Kasım 1912 saat 15.15'te başlayan bombardıman, 28-29 Kasım'da Karaağaç Mahallesi’ne düşen mermilerle etkili olmaya başlamış ve 3 Aralık gecesine kadar devam etmişti. Ateşkes görüşmeleri esnasında dahi fasılalarla saldırı sürmüştü.” (Örenç, A. F. 2012: 58)

22 Edirne Kalesi: "Şehrin nüvesini teşkil eden kale, Tunca kenarında bugün Kaleiçi denilen yerde bulunmaktaydı. Kalenin dört kulesi (Büyük Kule, Yelli Burgaz, Germekapı Kulesi, Zindan Kulesi) ve dokuz kapısı vardı. Geçirdiği tahribat ve tabiî âfetler sonucu kaleden bugün sadece saat kulesi kalmıştır." (Gökbilgin, 1994: 425-431).

23 Mehmed Şükrü Paşa'nın Balkan Savaşı sırasında yazdığı vasiyeti: "Düşman hatları geçtikten sonra ölürsem, kendimi şehit kabul etmiyorum. Beni mezara koymayın. Etimi itler ve kuşlar çeke çeke yesinler. Fakat müdafaa hattımız bozulmadan şehit olursam, kefenim, lifim, sabunum çantamdadır. Beni bu mahale gömeceksiniz ve gelen nesiller üzerime bir âbide dikeceklerdir."
} 
Şair, muhayyilesinde Edirne'den şimale doğru ilerlerken kaybedilen Rumeli toprakları içinde yer alan ve bir zamanlar Türk bayrağının dalgalandığı Filibe, Şumnu, Sofya ve Kızanlık’ı görür. ${ }^{24}$ Tıpkı geçmişte olduğu gibi Kızanlık’tan gül kurusunun geldiğini hayal eder. Bulgaristan'da eski bir kaza merkezi olan Kızanlık’ta (Kazanlık) (Kiel, 2002: 138-140) 180o'lü yıllarda çok sayıda gül bahçesi vardır ve buradaki güllerden gül yă̆ı elde edilir. Tarihî kaynaklar, halkın o dönemde Edirne’ye bağlı Filibe, Kızanlık, İslimye kazalarında dört bin dönüm gül bahçesini işlediğini ve buralardan elde edilen güllerden gül yağı çıkarıldığını kaydetmektedir. ${ }^{25}$ Safiye Erol, Osmanlı döneminde Anadolu'da Isparta, Rumeli'de ise Edirne'nin gül yetiştiriciliği ile öne çıktıklarını belirtir. Üçüncü Murad, bir fermanında Edirne Kadısı ve Bostancıbaşısı'na saray bahçesi için 200 kantar kırmızı gül ile 200 kantar sakız gülü siparişi verir. Yazara göre Edirne'nin böyle büyük bir siparişi tedarik etmesi, şehrin bütünüyle gülistan olduğunu gösterir. (Erol, 2010: 299-301)

\section{Sarayiçi}

Arif Nihat Asya, şehri, maziye özlem duyarak hüzün içinde anlatmaya devam eder:

"Şurda 'Sarayiçi’ derler, yoluna / Dünyanın en güzel korusu gelir.

Şimdi ışıların köpük gibisi, / Şimdi gölgelerin koyusu gelir.

Kırkpınar'dır: birbirini tartmaya / 'Benim' diyenlerin pazusu gelir.

Kar kalabalık, adaya kol kol.. / Yolcusu, izcisi, avcısı gelir.” (Asya, 2017: 87)

Şairin "dünyanın en güzel korusu” olarak tasvir ettiği Sarayiçi, II. Murad tarafından Tunca sahilinde H. 854 / M. 1450 tarihinde yapılmaya başlanan saraya ait yeşil alandır. (Rıfat Osman, 1989: 21)26

24 Günümüz şairlerinden Uluğ Turanlıŏlu da "melül Edirne”yi anlattığı "Edirne ve Rumeli” adlı şiirinde "eski vatan beldeleri” olarak nitelediği Budin, Plevne, Vidin ve Kızanlık’ın ufuklarında hâlâ ay-yıldızlı Türk bayrağının dalgalandığını hayal eder. (Turanlığlu, 1987: 89.)

25 Edirne'de "gülcülük", çok eski tarihlere dayanır. Belçikalı bir tarihçi, 1210 yılında Haçlı seferleri sırasında Haçlıların Edirne'de geniş gül bahçeleri gördüklerini kaydeder. Osmanlı kaynaklarında gülcülüğe dair bilgiler 16. Yüzyıla dayanır. Abdurrahman Hibrî, 1635 yllında tamamladı̆̆ı Enîsü’l-Müsâmirîn adlı eserinde Edirne'nin kokusu miske benzeyen gülsuyundan bahseder. Kâtip Celebi, Cihannümâsı'nda Edirne'nin üç nehrinin etrafinda 450 adet bahçe ve gül bahçelerinin çokluğundan dolayı şehrin başlıca ürününün gülsuyu olduğunu belirtir. Evliya Çelebi, 1640 yllında gördüğü Edirne'de gül bahçelerinin yer aldığı Hızırlık ve diğer bahçelerden bahseder. Edirne güllerinden hazırlanan gülsuyunun kalitesinin çok iyi olması sebebiyle bu gülsuları Osmanlı padişahlarına hediye olarak sunulur. 16. Ve 17 yüzyıllarda Topkapı Sarayı'nda görevliler tarafından tutulan “Helvahâne Defteri”nde saray için kullanılan taze gül yapraklarının ve gülsuyunun Edirne'den geldiği yazılıdır. Saraya alınan malzeme miktarı bir seferde 10 kantar gül şurubu, 120 kıyye gülbeşeker olarak kaydedilir. Bu kayıt imalatın büyüklüğü hakkında bir fikir vermesi bakımından önemlidir. Başbakanlık Osmanlı Arşivi'nde 1632 tarihli bir fermanda padişah için her yll hazırlanan gül şurubunun Edirne'nin kızıl ve sakız güllerinden yapıldığı yazllıdır. Edirne sarayının (1878 tarihli) haritasında gül fidanlarının dikildiği "Gülhâne" bulunur. Bulgaristan'da (Eski Zağra, Karlıva ve Kızanlık) Türkler tarafından kurulan gül bahçeleri, 1877-78 Türk-Rus savaşında Bulgarlara geçer. Savaştan sonra Türkiye’ye gelen göçmenler, getirdikleri gül fidanları ve bildikleri teknikler ile birçok yerde (İstanbul, Bursa, İzmir, Isparta, Burdur) gül yetiştirmeye başlarlar. (Altıntaş, 2003: 3-9.) Pars Tuğlacı ise IV. Murad zamanında İstanbul saraylarının bahçesindeki gülleri aşılamak için Edirne'den birkaç aşıcı kadının getirildiğini kaydeder. (Tuğlacı, 1985: 105.)

26 Edirne Sarayı, Saray-ı Cedîd-i Âmire, Tunca Sarayı, Hünkâr Bahçesi Sarayı ve Edirne Saray-ı Hümâyunu gibi çeşitli isimler ile bilinir. Fatih Sultan Mehmet tarafindan tamamlanan saray, Kanuni Sultan Süleyman, II. Selim, IV. Mehmet, II. Ahmet ve II. Mustafa tarafından genişletilir. (Rıfat Osman, 1989: 21.) Edirne sarayı, kapladığı alan, dairelerin, kasırların çokluğu yönüyle Osmanlı sarayları arasında “dağınık bir sahada en geniş saray” olarak kabul edilir. (Aslanapa, 2013: 120)

Sarayın yeri ile ilgili olarak Evliya Çelebi de II. Murad'ın Tunca kenarında "Havernak kemerleri ve nice tumturaklı dokuz-kubbeli kuleli yüksek köşkler" inşa ettiğini, "İrem bağı" olarak adlandırdığı bu yere her padişahın bir eser eklediğini, âdeta "cennet bahçelerinden Rıdvan bahçesi” olduğunu ifade eder: "Edirne şehrinin kuzey tarafı dıșında bir alçacık yeşillik ve lâlelik zeminde Tunca nehri her tarafını kuşatmış ada, bir genişçe, verimli, havadar arsaya kurulmuş Osmanoğlu bahçesidir. Bir tarafi tâ Saraçhane Köprüsü’ne varıncaya kadar göklere doğru baş uzatmış söğüt, çınar, servi, karaağaç ve kavak ağaçları ile süslenmiş bir meşelik ve güllüktür. Bu gölgelik içinde yaratık türlerinden nice kuşlar, hayvanlar ve yabanî hayvanlar dopdoludur. Bu bağın güney tarafı yeşillik sahradır ki o tarafa açlk bir kapı (bâb-ı hümâyun) vardır.” (Evliya Çelebi, 2010: 592.) 
Arif Nihat Asya, eskiden Sarayiçi denilen yerde bulunan padişah sarayı, vezir köşkleri ve paşa, bey, ağa konaklarından birinin bile ayakta kalmadığını, şehirde ayakta kalan cami, medrese, hamam ve kervansaraylar da olmasa hiç kimse Edirne'nin doksan bir yll Osmanlı Devleti’ne başkentlik yaptığına inanmayacağını üzüntüyle dile getirir. Ona göre Osmanlı döneminde "Darü'l-Mülk, Pay-ı taht, Mutluluk Kapısı, Yardım Kapısı, Ordu Şehri, Sinan Şehri, Büyük Şehir, Dünyanın Sırrı” adı verilen Edirne, Balkan Savaşları ve I. Dünya Savaşı'ndan sonra ise "viran şehir, yakılan-yıkılan, terk edilen" şehir haline gelir. Şair, Edirne'nin o haline bakıp ağlar. Edirne'nin geçmiş yıllardaki güzelliklerini okuduğuna pişman olur: "Ah keşke ben, Edirne'nin eski güzelliklerini hiç okumasaydım, hiç bilmeseydim." Edirne'nin eskiden "rüya şehri” olduğunu düşünen şair, şehrin yeni halini çiçek hastalığı geçiren birinin “yaralı yüzü”ne benzetir. 1877-78 Osmanlı-Rus Savaşı'nda Edirne'deki padişah saraylarının vezir, sadrazam köşk ve konaklarının Ahmet Eyüp Paşa tarafından cephane ile doldurulması ve savaşın kaybedilme tehlikesine karşı Rusların eline geçmemesi için bu cephaneliklerin dolayısıyla saray, köşk ve konakların havaya uçurulmasını örnek göstererek, Edirne'yi sadece Bulgarların değil, bizim de yakıp yıktığımızı ifade eder. Bu korkunç hadise karşısında üzüntüsünü şöyle ifade eder: "O dehşetli facia karşısında, ben de yüzümü ellerimle kapayarak gözyaşı döktüm." (Bakiler, 2010: 244-245)

Şair, şiirin devamında "Kırkpınar'dır: birbirini tartmaya / "Benim" diyenlerin pazusu gelir. / Kar kalabalık, adaya kol kol.. / Yolcusu, izcisi, avcısı gelir." diyerek Edirne'nin Sarayiçi mevkiinde tarihî bir gelenek olarak günümüzde hâlâ devam eden Kırkpınar27 güreşlerinden, güreş müsabakalarını izlemeye gelenlerden ve yine burada avcılığın ${ }^{28}$ iyi bir uygulama yeri olması bakımından avcılık yapmak için gelenlerden bahseder.

\section{Edirne'de akşam}

Şaire göre Edirne'nin akşamlarından da söz etmek icap eder. Zira onlar güzellikleriyle bize türlü çağrışımlar yaptırırlar:

"Bekle akşamı ki akşam, dalların / Bülbülü, ishakı, puhusu gelir.

Doldurur rüyanı eski âlemler: / Şarap, altın taslar dolusu gelir.

Açma son sayfayı ki yüreklere / En asil intikam duygusu gelir...

/ Ve yeminlerin en kutlusu gelir.

Şu dalları yaprağından öpmeye / Gökyüzünden samanuğrusu29 gelir.

Biz geldik, gideriz... doğacaklara / Edirne'de doğmak arzusu gelir.” (Asya, 2017: 88)

Edirne Sarayı'nın Hadika-i Hassa'sı (Has Bahçe) ise, Sarayiçi ve Tavuk Ormanı adı verilen ağaçlık olup Edirne’nin koruluk yerlerinden biridir. (Tosyavizade Rifat Osman, 2013: 102.)

Yine Tarih-i Edirne, Hikâyet-i Beşir Çelebi adlı eserde Hekim Beşir Çelebi'nin, sarayın bulunduğu mevkiin havasını övmesi sebebiyle Fatih Sultan Mehmet’in ona uyarak buraya saray inşa ettirdiği ve kemal sahibi âlim bir padişah olan Fatih Sultan Mehmet’in, âlimlere sevgisi olup nerede âlim ve fazilet sahibi birinin olduğunu duysa hemen onu getirtip sohbetler ettiği anlatılır. Hekim Beșir Celebi de ilmî donanımı ile Fatih Sultan Mehmet’in ilgisini çeker ve padișah tarafından Karaman'dan getirtilir. Fatih Sultan Mehmet, Tunca kenarında bulunan köşkünde Beşir Çelebi ile ilmî sohbetler eder. (Tarih-i Edirne, Hikâyet-i Beşir Çelebi, 1960: 2-4).

27 Her yll temmuz ayının ilk yarısında Edirne'nin Sarayiçi mevkiinde düzenlenen Kırkpınar güreşlerinin tarihi Orhan Bey zamanına kadar gider. Rivayete göre bu güreşler, Orhan Bey’in kardeşi Süleyman Paşa’nın Rumeli'ye geçerken yanında bulunan kırk gazi yiğidin o civarda güreşmesiyle başlar. (Özcan, 1996: 320.)

28 Osmanlı Devleti’nin "avcı" lâkabıyla bilinen padişahı IV. Mehmed, yaklaşık otuz beş sene süren saltanatında, bir ihtiras haline gelen ve tahttan indirilmesinin başlıca sebeplerinden biri olan av merakı ile, günlerinin çoğunu Edirne'de geçirir. Sarayda avcılı̆̆ın yanında at yarışları, cirit oyunları, tüfek ve ok müsabakaları, pehlivan güreşleri düzenler (Rıfat Osman, 1989: 31-33; Özcan, 2003: 414-418).

29 Samanuğrusu: "Samanyolu." (TDK, 2005: 1694.) 
Edirne üç nehirden beslenen münbit toprakları, ağaçlıkları, bahçeleri ve yeşillikleri üzerinde çok çeşitli kuşları da barındırır. Bülbül bunların başında gelir. Şair, akşam olunca ağaçların dallarına konan bülbüllerin ötüşleri, ishak ve puhu kuşlarının sesleri ile eski günlerin ihtişamını ve yaşanan büyük acıları düşünerek rüyaya dalar. Diğer yandan Edirne akşamları, şairi "eski âlemler"e götürür. "Altın taslar" tamlaması, zenginlik ve ihtişamla beraber yaşama zevki ve heyecanını ihsas eder. Aynı mısraa bir başka açıdan bakıldığı takdirde Edirne'de gurup vaktinin, kendine has kırmızısı ile şaire şarabı hatırlattığı da söylenebilir. ${ }^{30}$ Fakat şair geçmiş zamanlarda fazla kalamaz, hale ve realiteye döner. "Son sayfa” derken Türklerin, imparatorluğun son yüzyılında Balkanlardan atılışını, uğradıkları mezalimi, kaybedilen vatan topraklarını ve yaşanılan göç facialarını kasteder. Bütün bunlar onda "en asil intikam duygusu"nu doğururken, bu intikamın yemini de "en kutlu yemin" olur. Şair, şiirinin sonunda Edirne'nin, her şeye rağmen, pek güzel ve pek kıymetli bir şehir olduğunu, dolayısıyla insanların orada yaşamayı bir talih saydıklarını ifade için “... doğacaklara Edirne'de doğmak arzusu gelir” der.

\section{Sonuç}

Tarihte Türk ilim, sanat ve kültür hayatının önemli merkezlerinden olan Edirne, Osmanlı Devleti’ne doksan iki yıl başkentlik yapmış bir şehrimizdir. İstanbul'un fethi hazırlıkları ve plânları yine burada yapıldığı gibi, Balkanlara yapılan seferlerde de Edirne bir harekât üssü olarak kullanılmıştır. O, tarihten miras kalan zenginlikleri ve eserleri, tabiî güzellikleri, gelenek ve görenekleriyle geçmişten günümüze Türk şiirine konu olmuştur. Türk edebiyatının "bayrak şairi” Arif Nihat Asya da Edirne'yi kuvvetli sanatkâr ruhu ve onu besleyen ilmî ve fikrî donanımı, tarih şuuru, din duygusu ve vatan aşkıyla "Edirne Kasidesi” adlı şiirinde anlatmıştır. Öğretmenlik görevinin icabı olarak 1948 yılında Edirne'ye gelen ve o tarihten önce şehri hiç görmeyip ona dair bilgileri kaynak eserlerden okuyan şair, şehrin halini görünce hayal kırıklığına uğramış, şiirin muhtevasını oluşturan Edirne'nin tarihî eserleri, nehirleri, güzelleri ve geleneklerini geçmişteki ihtişamı ve güzellikleri ile hatırlayıp hayranlık ve gurur; yitip giden, yıkılan eserlerini, kaybolan değerlerini hüzün, hayal kırıklı̆̆ı ve öfke ile muhayyilesinde canlandırmış, onları orijinal hayaller, motifler, teşbihler vasıtası ile şiirleştirmiştir. Onun bu şiirini okuyanlar, Edirne tarihi ile beraber Osmanl-Türk tarihinin mesut çağları ile trajedi dönemlerini birlikte idrak edip özelde Edirne, genel bütün Türklük coğrafyası üzerinde yeniden tefekkür ihtiyacını duyacaklardır.

\section{Kaynakça}

Abdurrahman Hibrî (1999). Enîsü’l-Müsâmirîn (Edirne Tarihi) (R. Kazancigil, çev). İstanbul: Edirne Valiliği.

Ahmet Bâdi Efendi (2014). Riyaz-ı Belde-i Edirne I. Cilt (N. Adıgüzel-R. Gündoğdu, haz.). İstanbul: Trakya Üniversitesi Yayını.

Altıntaş, A. (2003). Edirne’de Gülcülük ve Edirne Gülü. Yöre Aylık Kültür Dergisi, (34), s. 3-9.

Aslanapa, O. (2003). Edirne'de Osmanlı Devri Abideleri. İstanbul: Edirne Valiliği.

Asya, A. N. (1976). Duâlar ve Âminler. İstanbul: Ötüken Neşriyat.

Asya, A. N. (1976). Ses ve Toprak, İstanbul: Ötüken Neşriyat.

Asya, A. N. (2017). Kökler ve Dallar. İstanbul: Ötüken Neşriyat.

Ayverdi, S. (1975). Türk Tarihinde Osmanlı Asırları I. İstanbul: Damla.

Bakiler, Y. B. (2010). Ârif Nihat Asya İhtişamı. İstanbul: Türk Edebiyatı Vakfı.

3o Edirne, gurup vaktinde batı ufkunda oluşan renk ve tablolarıyla da farklı güzelliğe sahip şehirlerimizden biri olarak kabul edilmektedir. 
Beyatlı, Y. K. (2008). Eğil Dağlar. İstanbul: İstanbul Fetih Cemiyeti.

Bozkurt, N. (2003). Mahya. TDV İslâm Ansiklopedisi 27. C. (s. 396-398). Ankara: TDV.

Can, E. (2003). M. Niyazi Akıncıŏglu ve Edirne'ye Dair Siirleri. I. Edirne Kültür Araştırmaları Sempozyumu Bildirileri (s. 297-311). Edirne: Trakya Ủniversitesi Fen-Edebiyat Fakültesi Türk Dili ve Edebiyatı Bölümü.

Can, E. (1997). Tarih ve Estetik Perspektifinden Edirne. Oluşum. 5(17), 8-9.

Çandır, K. (2014). Enis Behiç Koryürek’in Hayatı, Sanatı, Eserleri (Yayımlanmamış Doktora Tezi). Gazi Üniversitesi Sosyal Bilimler Enstitüsü, Ankara.

Çoruhlu, T. (2012). Tŭ̆. TDV İslâm Ansiklopedisi 41. C. (s. 330-332). İstanbul: TDV.

Dursun, A. H. (2011). Ayasofya Müzesi Kültür Envanteri. İstanbul: İstanbul Bilgi Üniversitesi.

Emekligil, R. (2013). Geçmişin İzinde Karaağaç. İstanbul: Edirne Valiliği.

Erol, S. (2010). Yediveren. Makaleler (H. Açlkgöz, haz.) (s. 299-301). İstanbul: Kubbealtı.

Evliya Çelebi (2010). Günümüz Türkçesiyle Evliya Çelebi Seyahatnâmesi 3. Cilt / 2. Kitap (S. A. Kahraman-Y. Dağlı, haz.). İstanbul: Yapı Kredi.

Gökbilgin, M. T. (1994). Edirne. TDV İslâm Ansiklopedisi 10. C. (s. 425-431). İstanbul: TDV Yayınları.

Gürgendereli, M. (2016). Osmanlı Dönemi Şïirinde Edirne, İstanbul: Çantay.

İnalcık, H. (1993). Edirne'nin Fethi. Edirne’nin 6oo. Fetih Yıldönümü Armağan Kitabı (s. 138-159). Ankara: Türk Tarih Basımevi.

Kahrıman, Y. (2017). Edirne Tarih Sözlüğü, Edirne: Eser Matbaacılık.

Kestelli, R. N. (2001). Ufûl (Osmanl İmparatorluğu'nun Batışl), (V. Özdemir, haz.). İstanbul: Arma.

Kiel, M. (2002). Kazanlık. TDV İslâm Ansiklopedisi 25. C. (s. 138-140). Ankara: TDV.

Koryürek, E. B. (1971). Mîras ve Güneş’in Ölümü (F. Tevetoğlu, haz.). İstanbul: Millî Eğitim Basımevi.

Kuban, D. (1997). Sinan’n Sanatı ve Selimiye. İstanbul: Türkiye İş Bankası Kültür Yayınları.

Kuruyazıcı, H. (1993). Selimiye Camisi'nin Kubbe Boyutları. Tarih ve Toplum Ayllk Ansiklopedik Dergi, 20 (120), 24-27.

Montagu, L. (1998). Şark Mektupları. (A. Refik, haz.). İstanbul: Timaş.

Önder, M. (1998). Atatürk’ün Edirne’ye Gelişleri. Kültür ve Sanat Dergisi / Edirne Özel Sayısı, (39),69.

Örenç, A. F. (2012). İngiliz Belgeleri'nde Balkan Harbi Edirne Kuşatması 1912-1913. Trakya Üniversitesi Edebiyat Fakültesi Dergisi, 2 (4), 58.

Örenç, A. F. (2013). Edirne Muhasarası ve Mehmed Şükrü Paşa. 10o. Ylldönümünde Balkan Savaşları ve Edirne Sempozyumu (s. 103-134). İstanbul: Edirne Valiliği.

Örik, N. S. (2000). Anadolu'da-Yol Notlart-Bir Edirne Seyahatnâmesi, İstanbul: Arma.

Özcan, A. (1996). Güreş. TDV İslâm Ansiklopedisi 14. C. (s. 317-320)İstanbul: TDV.

Peremeci, O. N. (2011). Edirne Tarihi. Edirne: Bellek.

Rıfat Osman (1989). Edirne Sarayı (Süheyl Ünver, yay.). Ankara: Türk Tarih Kurumu.

Sâî Mustafa Çelebi (2003). Tezkiretü'l-Bünyan ve Tezkiretül-Ebniye (Mimar Sinan’n Anıları) (Hayati Develi, haz.). İstanbul: K Kitaplığı.

Tarih-i Edirne, Hikâyet-i Beşir Çelebi (1960). (İsmail Hikmet Ertaylan, yay.). İstanbul: İstanbul Üniversitesi Edebiyat Fakültesi.

TDK, (2005 ). Türkçe Sözlük. Ankara: Türk Dil Kurumu. 
Topaloğlu, Y. (2007). Ahmet Kutsi Tecer ve Arif Nihat Asya'nın Şiirlerinde Edirne. Trakya Üniversitesi Sosyal Bilimler Dergisi, 9 (1), 192-211.

Tosyavizade Doktor Rıfat Osman (2013). Edirne Rehnüması (Edirne Şehir Kılavuzu). Ratip Kazancıgil, haz.). İstanbul: Edirne Valiliği Kültür.

Tosyavizade Doktor Rifat Osman, (2015). Millî Mecmua'daki Edirne Abideleri Yazıları (Recep Duymaz-Yüksel Topaloğlu, haz.). Edirne: Trakya Üniversitesi.

Tuğlacı, P. (1985). Osmanl Şehirleri. İstanbul: Milliyet.

Turanlığlu, U. (1987). Edirne ve Kırkpınar Şïrleri. İstanbul: Edirne Lisesi'nden Yetişenler Derneği.

Yıldız, S. (1994). Arif Nihat Asya’nın Şiiri (Doktora Tezi). Trakya Üniversitesi Sosyal Bilimler Enstitüsü, Edirne.

Yıldız, S. (1997). Arif Nihat Asya'nın Şïr Dünyası. İstanbul: Millı̂ Eğitim Bakanlı̆̆ı.

Yücel, E. (1993). Çekmece. TDV İslâm Ansiklopedisi 8. Cilt (s. 251-252). İstanbul: TDV.

https://www.hurriyet.com.tr/seyahat/asirlardir-ayakta-olan-selimiye-camisi-500-yil-icindeolabilecek-depremlere-de-dayanikli-41445481, erişim tarihi: 30.03.2020.

https://www.ntv.com.tr/turkiye/floransadan-sonra-en-cok-edirnede,RZ7G9UP3Ko2dNhIXAbz2XQ, erişim tarihi: 09.03.2020. 